\author{
ANUBHAV SENGUPTA \\ Manipal University \\ anubhavsengupta@gmail.com
}

\title{
WHO IS THE PEOPLE? NOTES ON SUBJECTIVITY AND THE ADIVASI RESISTANCE IN LALGARH, WEST BENGAL, INDIA
}

\begin{abstract}
In the last decade, India has witnessed a resurgence of Maoist movements. At the same time, the country's polity has been rocked by various protests against displacement by local population. These protests have commonly been referred to as people's movement. In some cases, both, Maoists and people's movements have overlapped and thus raising the question about people's agency and Maoists' role in it. This essay posits the question: who is this people? The assumption is only by exploring the answer, questions pertaining to autonomy or agency can be answered. The essay takes the case of Lalgarh movement, West Bengal, where adivasis rose up against the state, police atrocities. Subsequently Maoists came into the picture. In exploring the debate, mentioned above in the context of Lalgarh, the essay studies a set of letters written to civil society, issued by an organization on behalf of adivasis. The essay finds that the issues of agency must be reconceptualised as subjectivity. Instead of finding a pure voice of adivasis, it is subjectivity as process that helps us to grasp politics of the people. The paper finally argues that the process of becoming people is congealing of adivasis as a political collective.
\end{abstract}

Keywords: Maoist movements, people's movement, subjectivity, history, everyday.

Maoist movements, principally led by the Communist Party of India (Maoist) ${ }^{1}$ have recently taken a back seat in political discourse of India. Since their emergence in 2004, for almost a decade, Maoist movements across the country had been drawing attention to issues of displacement, marginalization, exploitation and most importantly the relevance of revolution in a country like India. During the decade, Maoism as a word evoked (and still perhaps continues to evoke in certain quarters) strong emotion and passion. Around 2004-2006, CPI(Maoist), to their credit brought to the fore issues of structural violence, combining state repression on people and absolute impoverishment of the same. To their disadvantage, the public and intellectuals focused more on spiraling state-violence and counterviolence of the rebels. Between forms of violence and its legitimacy, the line was

${ }^{1}$ Now on CPI(Maoist). 
sharply drawn and debate over revolutionary politics meant passionate arguments over (il)legitimacy of Indian state and the need and scope of revolutionary transformation employing violent means. Little later, it is only with movements against displacement - not necessarily led by Maoists - emerging across the country, the attention shifted to dire state in which a large section of the country's population has been living.

By 2006-2007, in West Bengal, a state located on the eastern part of the country, the last trend mentioned above was clearly visible. It is important to mention here, by then the state had been under a communist regime (Communist Party of India (Marxist) for 34 years at a stretch. There had been sporadic protests in the state, but no full-blown movement over these years. It was in 2006, a militant protest broke out in Singur, Hooghly district against TATA motor factory's acquisition of agricultural land. Touting the rhetoric of industrialization, CPI(M) was giving away land to TATA and even mobilized police, cadres to force peasants to let go their land, often against a disproportionate compensation. People of Singur resolutely resisted such attempt and with the solidarity of other political parties, it became a "people's movement". By 2007 similar resistance reached Nandigram. West Medinipur district. This time state violence escalated; so did intensity of "people's struggle". The movement did not shy away from armed resistance as villagers dug up roads, guarded various entry points with traditional weapons to keep state machineries at bay. There were some rumours of Maoist presence in Nandigram but it still largely remained a "people's movement" in the imagination of public. In 2009 when the resistance broke out in Lalgarh - part of the region, historically called Jangal Mahal and inhabited by adivasi ${ }^{2}$ population - the character had decisively and qualitatively changed. Following the same pattern, adivasis dug up roads and guarded these strategic points with traditional weapons. However it was also an open secret that CPI(Maoist) was the backbone of the movement. People's Committee against Police Atrocities (PCPA), with Chatradhar Mahato, as the leader and spokesperson of PCPA was leading the movement. But soon CPI(Maoist) politburo member, Kishenji declared it to be a Maoist backed movement. From this point onwards, the idea of "people's movement" overlapped with the ideal of Maoist movement. One strand still believes that the Maoists hijacked a "people's movement" by imposing their political goals of the violent seizure of state power in the name of people's revolutionary aspirations. Thus for them "people's movement" and Maoist movement are contradictory to the extent that the latter could subvert the former (Nigam 2009). On the other hand, for few, there was no opposition between spontaneity of "people's movement" and program of revolutionary politics. The revolutionary subjectivity of the "people" must be recognized (Giri 2009, 2009a).

With the demise of Lalgrah movement and subsequent erasure of Maoist politics from national political discourse, an attempt may be made to cast an objective look into the matter and recover materials that remained outside debates and analysis. From the debate mentioned above, it is easy to discern that the main contention is between two forms of politics: "people's movement" and revolutionary

2 I shall be using adivasi in this essay, instead of tribal because of prevalent use of the former in academic and political circle. More importantly this term has been consistently used in my sourcematerial. 
politics of the Maoists. Literature also seems to suggest, to understand these two forms of politics, one must recover the category of (political) subjectivity (Nigam 2010; Menon 2009; D'souza 2009; Bhattyacharya 2010). Simply put, the question is: did Maoists rob "people" of their consciousness and action or strengthened it. While of course this debate cannot be settled within the scope of this paper, however an attempt can be made to understand political-sociological logic of "people's" politics and place of subjectivity or consciousness in it. A chief concern, following the issues raised above is also the question: how does this "people" come about and how is it different for example from adivasi villagers?

This essay attempts to analyse six letters written from Lalgarh addressing civil society, human rights activists and intellectuals (Sanhati 2013). These letters touch upon myriad of important issues; however remained largely ignored. In this attempt, one finds how these letters time and again give justification to barricading the state off Lalgarh, by informing readers about the condition of living in Lalgarh. In the same context it also tries to justify the form of politics that people of Lalgarh adopted. They appeal to readers to take note of socio-political conditions in Lalgarh and then discern what might have forced people to take such radical measure in their resistance to the state. The signatory of these letters is PCPA. They claimed to lead the movement initiated by the people. However their claim of representing people can hardly be taken at face value. In fact with the presence of CPI(Maoist) and allegation of PCPA being a Maoist front and thus banned by the state, any claim of finding people's experiences or subjectivity in these letters is fraught with difficulties.

\section{Methodological Dilemma}

In the absence of definite proof, it is methodologically more prudent position to accept that there is no way to separate Maoists, PCPA and people. This implies acknowledging that representation of people in these letters is anything but authentic. In spite of that when one takes note of certain facts and patterns, an attempt may be made to answer the set of questions raised above. A cursory glance is sufficient to locate the fact that the language of the letters is markedly different from any official discourse of the Maoists. Despite occasional presence of politicalconceptual terms and snippets of political analysis, otherwise all pervasive in Maoist official discourse, the effort in these six letters is to present the discourse in a language that differs. This difference itself could be a fascinating object of study. However in our context, it suffices to point out that the major difference lies in how events have been narrated. The narrative trope is more descriptive and invites its readers to interpret political implications of such events. It is a significant departure from the Maoists official discourse, plotting events rather as evidence of revolutionary transformation to come. Thus even if written by the Maoists, or Maoist-front PCPA on behalf of adivasis of Lalgarh, there is an attempt to represent adivasis as the collective and author of these letters.

Few issues still remain. Was there ever a people, a political collective, born out of adivasis? What if the Maoists ideologically constructed people in order to garner opinion against the state's counterinsurgency operation? Ironically answers to both question are yes. PCPA, on behest of the Maoists or not, was indeed writing these letters in order to gain sympathy from civil society and thus public opinion against state's counterinsurgency. However at the same time it cannot be said that people 
to be found here was an ideological construction. Adivasis coming together as a collective is documented by independent sources. Sources also documented their spontaneous anger and resistance to the state in initial days and subsequent participation in formation of PCPA and its everyday functioning. An interview of an activist, conducted by Tanika Sarkar and Sumit Sarkar (2009) - India's foremost historians - and published alongside their thoughts on the movement, describes, on 5 November, about eight to 10,000 people from 50 villages gathered at Doloipur Chowk at Katapahari, and formed the Polishi Santrosh Birodhi Janasadharener Committee (the People's Committee against Police Violence), and decided to blockade all roads leading to Lalgarh. Roads were dug up and trees felled, and within a couple of days the blockade spread to all of Jangalkhand, and even to the tribal areas in North Bengal, Bankura, and Purulia... Each decision related to the movement is taken collectively at gatherings that are 15-20,000 large. Tribals gather from distant villages at an appointed central place. These are open meetings and no party banners are allowed, although occasionally members of opposition parties have attended them without banners... The movement now encompasses more than 200 villages, and involves more than one lakh people. Village committees have been set up through open deliberations reached in mass meetings in BankuraPurulia-West Medinipur. Each is constituted in an open meeting of about 15,000 people. At these meetings, even outsiders can have their say, and be a part of the final decision-making process. (p. 12-14)

Keeping PCPA's representation of people in the letter and at the same time people's presence on the ground as fact, I argue these letters can indeed help us understanding the process of coming together of adivasis as a collective and commonly referred to as people. White (2000) canvasses vampire stories circulating in colonial Africa. He observes though there were wide variations in ways these stories were told in different parts of the region, one observes a pattern or what he calls genres emerging out of these stories. In other words, in our context facticity is not so much important while reading these letters. It is rather the structure and structuring of a narrative keeping people in the center that one should focus upon. This narrative as already pointed out can be ideologically motivated or driven by ulterior motive. However given the people did exist also means these letters are bound to contain traces of the process of becoming, from individual adivasis to the collective, namely people. Traces, however do not imply voice of the people as subject. The subject's voice is always-already ideological. But at the same time subject's voice retains real condition of speaking out. Ideology constitutes subject's imaginary relationship with real condition of living (Althusser 2006). To recover this real, suppressed by ideological process, I shall argue for subjectivity as a process involving movement of consciousness and show how it expresses itself in the movement of becoming people.

Reading a narrative-structure: Althusser and Subjectivity without a subject

Althusser's (in)famous thesis, mentioned above met with serious challenges from certain quarters. In response to such criticisms, Alain Badiou (2005) argues that Althusser presented a new project whereby class-struggle or any form of resistance must not be thought in and through a category of 'subject', endowed with consciousness (steeped in the Enlightenment, ideological notion of Man); but 
consciousness must be conceptualized as an evolving process. Borrowing from Althusser, Badiou names this process "subjectivity without a subject" (Badiou 2005).

I shall argue such a notion of movement of consciousness or subjectivity without a subject can be traced back to his essay "The 'Piccolo Teatro': Bertolazzi and Brecht" in For Marx (2005). In the essay, which is a review of a theater production in France in July 1962, provides with clue that how movement of consciousness could be thought in relation to dual temporalities. Instead of a centered notion of consciousness, personified in rational Man, this short note invites its reader to think consciousness as a process unfolding through structural-relational properties of two temporalities present in human practices.

Althusser in the essay subjects the plot-structure of the play, El Nost Milan, to a structural-relational analysis. Althusser goes on to argue that this theater was actually a critique of melodramatic consciousness. His contention is, if one observes the play there were two distinct elements in the plot. One element involves three characters and their lives. Another element is the life of oppressed, life of the working class of Milan, Italy from that time. These two elements represent two temporalities for Althusser. One temporality is dialectical temporality - it is full in the sense of fantastic conflicts, events involving these three characters in their individual lives and which resulted into tragic ending for the character of a girl, who is the protagonist in the play. The other temporality is empty, unconscious order involving nameless, faceless characters coming from working class of Milan. Now the latter temporal order represents real condition of existence of working class from which these three characters come; while former represents the lived time of these three characters which is full of dialectics and conflict. In everyday living, two times stay non-related.

In this non-relation, the lived time appear to be true time of the subject (in strict sense in which he uses the term, in discussing ideology interpellates subject) and impute a melodramatic (ideological) consciousness. Althusser's argument is that the authentic political content of this theater production is to represent the non-relation between two temporal orders itself. By presenting both times on the stage and unlike other productions, the theater tries to posit a critique of the dialectical time as melodrama (ideological) itself. Caught in this melodrama of 'tragedy', the spectator, as a subject often misses out that the real tragedy is the real condition of these working class men and women for whom nothing ever changes, remaining forever the same.

Althusser claims that only when, a subject emerges from the fantastic dialectic of lived time, and may thus encounter the abstract empty time, movement of consciousness is possible. However he does not explain how in real life such movement is possible. Is it then the case that such movement is always contingent on external interventions, ranging from any cultural representation (like theater) to a party (e.g. Communist Party)? In what follows I shall show how abovementioned letters weave a narrative involving a dialectically full lived time, a historical empty time; and finally how from these narratives, one finds the story of adivasis congealing together as the people, a political collective. This congealing and becoming people is outcome of historical time appearing to individuals in its dissociation with everyday, lived time. The people then becomes the expression of the effort to connect the dissociation or unfolding of subjectivity (without a subject). 


\section{Living in Lalgarh: The Tragic Narrative of everyday}

Even a cursory reading of the letters, issued by PCPA provides a detailed account of living condition in Lalgarh over one year. Such information pertaining to what was happening during Lalgarh struggle is accessible to us also from independent sources like newspaper reports. But in case of these letters what draws attention is ways in which certain tragic incidents are weaved together to present a tragic narrative of living in Lalgarh. It involves elements such as death, body, secret and power. Reporting of Lalmohan Tudu's death in the first letter, sent by PCPA, dated 27/03/2010 could be a good starting point (Sanhati 2013: 9-32).

"Dead-body of Lalmohan Da": a secret

As the sequence of events can be gauged from PCPA's version of the event, it began with Lalmohan Tudu's journey to Kolkata and his stay from $19^{\text {th }}$ February till $22^{\text {nd }}$ February. During this period, he met several groups, ranging from intelligentsia, human right groups to political parties. His aim was to inform about the activities and programs of PCPA. He was also there to garner support for PCPA; by then it had been banned by the state government. On $23^{\text {rd }}$ February, in a radio bulletin, it was reported that in a clash between the Maoists and Central Reserve Police Force (CRPF), one Maoist had been killed. It was Lalmohan Tudu. PCPA rejects this version outright and claims that it was a fake encounter. They justify their claim by retelling the adivasi villagers' accounts. They reported that his body bore the bullet-marks, shot at a point blank range. There was also blood splattered around his house. Though not stated explicitly, but it was suggested that on his way from Kolkata he must have been trailed by police and then killed. It was then only reported as an encounter between the Maoists and CRPF.

There is no independent source, under our disposal, to verify the facticity of PCPA's claim about "fake encounter". But such a verification may not be so important, given what I am interested is in focusing our attention on the real bone of contention - how Lalmohan Tudu's body was never returned. Seemingly it was kept in the morgue in Jhargram, neighboring Lalgarh area. The state government refused to return it, citing no claim was made by his family. There were other civil rights activists who came forward and even filed cases. This effort also did not yield any result. The letter simply asks what happened to Lalmohan Tudu's body! This missing body of Lalmohan Tudu is a remarkable instance. The significance of disappeared body in political conflict has been reflected on in anthropological literature, pointing out its status in zone of exception, where it is neither dead nor alive (see Taussig 1992). In between the expectation of miraculous return and hopelessness of not being alive, its haunting existence is noted. Compared to a disappeared body, Lalmohan Tudu is a body which has definitely been killed but was not so much disappeared. It is rather not returned.

To understand this absence and the lack it refers to, one must dwell on what happened (according to PCPA) to Tudu before his killing. He was member of a "banned organization" (i.e. PCPA) visiting the seat of power i.e. state's capital and trying to mobilize support in such a hostile situation. So it has to be a fact, as PCPA alludes, that he was forced to move secretively. Evidently his secret movement was detected and he was killed subsequently. However, even in his death, as the letter seems to imply, the secret world surrounded him. It moved back and forth, perennially, between the symbolic worlds of judicial claim, democratic rights, 
state's discourse and even PCPA's claim to truth. But it nonetheless remained unreturned and thereby deprived of a resting place.

Max Weber in his sociology of the state, bureaucracy and power, notes the negative implication of a state ruled by bureaucracy and exercising its monopoly over secrecy as an expression of sovereign power (Gerth and Mills 1946: 233-234). The secret, surrounding Tudu's body of course has a very different context but it nonetheless indicates towards such sovereign exercise of exceptional power. By citing a legal norm, sovereign can even impose normlessness. It is to be noted that given his dead body is lying in morgue was no secret, it was his body itself, which had been kept as a secret. With distinctions between norm and normlessness erased, exceptional power of secrecy being exercised over a body, Lalgarh befits the description of a zone of exception. It is the narrative that even PCPA tries to weave by incorporating other, needless to add tragic narrative elements.

The secret at play: the sociality in Lalgarh

The secret that Tudu's unreturned dead body testifies to, is a world of secret networks that also surrounded life in Lalgarh. Raju and his "disappearance" from the same letter dated 27/03/2010 is an interesting case in point. Raju along with Jaydev were missing from January, 2010. They had remained untraceable for 4 months and PCPA finally declared them "martyr". At first glance it seems like a simple narrative. However there are breathtaking twists and turns in this. It begins with the peculiar expression used by PCPA in declaring Raju a martyr: "We were compelled to declare many such people as martyrs" (Sanhati 2013: 13). The peculiarity gets more complex with a narration of intervening period from Raju and Jaydev going missing and them being declared martyrs. What happened during those days?

After Raju and Jaydev went missing, on 20th January, 2010, Jaydev's daughter and Raju's wife were detained by the police. They were kept in custody for three to four days. The authority tried "luring" Raju's wife that if she would assist the police to trace PCPA leaders, Raju would be let go. This seems to be a simple terrorstrategy of blackmailing, and breaking down opposition through emotional torture. However, another set of interrelated issues must be taken note of. Where was Raju? Was he alive? Was he dead? Would they really let Raju go, if his wife complied? This secret about Raju's whereabouts is yet again a key element here. This secret configures the encounter between the police and Raju, Raju's wife and police, and even the relationship between Raju and his wife indirectly.

If Raju's wife started wondering about truth about Raju's disappearance, so was the case with villagers. Engulfed in a network of secret, the life was seamlessly weaved into a life of doubt, suspicion and disbelief,

From then two things have been worrying the villagers of the 8-10 villages of that area: who are those people maintaining secret nexus with the police and keeping vigil on the supporters and activists of the movement. The CPM and the police, paramilitary have adopted the strategy of dividing our people, of creating an atmosphere of doubt and disbelief. (p. 13)

It is a description of a population, which is being divided, assembled, reassembled with the power of a secret. The secret is just not an existential condition here but a strategy in itself. Disappearance of the persons does not just indicate stripping of their legal status, reducing them to a bare body in a shadowy land 
(Agamben 1998). But it is simultaneously putting that shadow of a bare body into the heart of a population - configuring social bonding: inter-personal relationships, inter and intra-group relationships. This is a world of secret networks. It can be termed as secret society. In employing the term, a logical distinction must be made. It is not a society which was deliberately or forced to become secretive with reference to sovereign power like the state; it was a society where the sociality was produced and reproduced, as people lived a life of suspicion and doubt. ${ }^{3}$

The secret society as a derivation of the existing relationship between state and the adivasis is further highlighted with the reappearance of Raju and Joydeb. In the sixth letter, dated 05/08/2010, PCPA writes that they were wrong in claiming Raju and Joydeb as martyrs. They had got information of them being produced in Jhargram court. However, this production of Raju and Joydeb in person was also not a simple affair. After almost 240 days of disappearance, they were finally brought before the court. Then also, they were charged under false names and identities. It was them who claimed themselves to be Raju and Joydeb. Admittedly, here the state of exception (Agamben 2005) is exemplified by the fact that a state can imprison someone for almost eight months beyond the purview of legality. But what is more significant in this context is the act of bestowing a false identity on them before law. Such falsity, strategy to confuse and mislead, according to PCPA was aplenty in Lalgarh. They give examples of Soma Mandi (whom they accept "may be a Maoist") who had faced a similar fate when she went missing for four months. In such cases, as PCPA indicates, the end result was invariably utter confusion and doubt, deliberately created by the state apparatuses by keeping secret any information about arrest and the conditions of detainment. It was the typical political order that engulfed the life in Lalgarh

The last day of Umaknato: the political order in Lalgarh

The last day of Umakanto was lived amidst such secret networks. His death was not simply a result of naked violence but a secretly weaved plan of perpetrating naked violence. It involved various actors. The truthfulness of the reporting by PCPA cannot be corroborated with enough precision from any independent source. However, more than the facticity, what needs emphasis here is the same structure of a secret world of nexuses and linkages. It was in this context of secret-order, the last day and eventual death of Umakanto is presented in the fifth letter, dated 09/08/2010 (Sanhati 2013: 109-141).

As PCPA account suggests he had been a politically active figure in the region for some time. He joined the movement led by PCPA in his early days and emerged as an important organizer inside the movement. Under his supervision, the development of various projects was underway. He also enjoyed broad mass support. On the day of his death, he visited his own village. He played football. After that he left for a village, called Damri, to attend a meeting. He left the meeting at $1 \mathrm{PM}$ in the afternoon. On his way, he was intercepted and killed. Later, state forces claimed that he had been killed in an ambush led by security forces. It was claimed to be a successful joint operation.

PCPA however decries this version and presents an intriguing account, which involves various actors and the secret world at play. They inform that Umakanto's visit to Damri village to attend the meeting was result of a secret plan hatched by

${ }^{3}$ A similar condition of living is described by Alpa Shah (2009) as ontological uncertainty. 
CPI(M) leader Prashanta Das. Then it was executed by CPI(M) cadres secretly present in the rank and file of PCPA. Later a detailed account follows, according to which , informed by these "secret agents", a "gang" of private militia led by Das was waiting for Umakanto and killed him from point blank range.

Umakanto's death, PCPA also claims is a new juncture in the history of atrocities in Lalgarh. It opened up a new phase where a killing by private militia was now claimed by state forces as successful "encounter". Their argument is that Umakanto's brutalized body was a material embodiment of a secret tie that bound legal force of police, CRPF etc. and an extra-legal force of private militia. No longer, the former was an extension of sovereign apparatus who by suspending itself opens up a space for private militia, such as Harmad to reign supreme. But now they were in secret ties with the private militia; they were in active service of the figures such Prashanta Das. This argument of PCPA does not actually need much elaboration.

Notwithstanding, whether or not this is what exactly happened to Umakanto, such violence had indeed been unleashed on the population, say for example in Nandigram. It was widely recorded in independent media how in state's attempt to break through the barricade in Nandigram and to enter the villages, police was accompanied by unidentified personnel present in plain clothes. There was also reporting of personnel clad in uniform, however wearing "chappals" instead of customary police boots (APDR \& BMC 2012). In the context of Chattisgarh, Nandini Sundar (2006) points out how Salwa Judum, a people's militia testifies to secret ties between legal state apparatus and extra-legal forces. Therefore even if PCPA's claim about the killing of Umakanto cannot be verified, the point of secret ties between state apparatus and the figures of exploitation (such as Anuj Pandey, Prashanta Das etc.) cannot be discredited. It is then the political configuration with its various apparatuses, ties and exercise of power, legally or extra-legally that determined the fantastic, eventful but at the same time tragic condition of living. Here tragedy is the seamless weaving of life and death in a zone of indistinction. However these six letters don't only speak of such evental, dense temporality involving actors, events and episodes. Alongside this, there exists another account, very subtly weaved along with these remarkable, dramatic narratives. It is a story about empty time, where for over a century nothing has happened to the effect of nothing has changed.

\section{The History as Empty Temporality}

A recurring theme in PCPA's letter is existing nexus between ruling classes. The letters insist on various modes of such nexuses. One form has been pointed out in the preceding section. However PCPA pleads its readers to understand that state-sovereignty and its repression did not come in one avatar. The form was always contextualized across time and space according to collaboration between and among ruling parties and ruling classes. It might take the form of CPI(M) as the ruling party and their vigilante group, Harmad; it might also take a shape of a cohort between state-police and Harmad; it could also be a combination of the Centre's paramilitary, police and Harmad. As an extension, structure of sovereignty was exposed as various combination of relations between 'ruling (class) parties' (like CPI(M), Congress, irrespective of their ideological differences), statemachineries and private militia. Even opposition parties might be co-opted in these alliances either indirectly or directly. Such apparently diverse forces could be 
claimed to come together to oppress people and safeguard interest of the TATAsJindals, i.e. the interest of the capital. In the very first letter, PCPA writes rather elaborately:

The war waged by the State and the Central Govt. in the name of "Operation Greenhunt" is directly destroying our lives and livelihoods in jangal mahal. The ultimate objective of the State and the Central Govt. is to loot the immeasurable natural resources of the Jangal mahal and the entire country for the Jindal, Mittal, Tata, Pasko, Sail, Ambani, Birla and other M.N.C.s, killing and obliterating the entire Adivasi population (Sanhati 2013: 1).

In the same letter, PCPA goes on,

The official declaration of the "Operation Greenhunt" has aggravated the situation. Not a single parliamentary party has opposed the central policy of deploying twenty-two thousands more paramilitary force in Jangal Mahal. From Chidambaram- Buddhadeb Bhattacharya to Mamata Banerjee everybody is involved in this. (p. 18)

Such convenient collaborations among political parties, ruling classes and capitalists however also had a 'timeless' dimension to it. Another argument that the letters repeatedly highlight is the fact that such exercise of unrestrained power was nothing new. So the state's claim that such unprecedented violence was response to Maoist-threat or adivasis' resorting to arms, is decried by PCPA. In fact they recall how Jangal Mahal had always been a lawless land. They write in their fourth letter:

To be frank there is no law in Jangalmahal. Before 2008, November, whatever CPM used to proclaim was law. Everyone knows this, it's not a secret. In any place the party which is strongest becomes the law. This is true in not only Jangalmahal, but in entire West Bengal and India. Be it Kolkata city or any mufassil, from the registration of houses to all office works nothing gets done without paying bribes to the political leaders. This is total mafia raj. (p. 83)

If such has been the past -- timeless reign of power over the lives of adivasis -the future did not seem to be of any great relief. The letters highlight the farcical claims of the political leaders, their empty promises to fight. Since the British era, the history had remained same for the adivasis and it was going to be so in near future as well. PCPA thus pleads its readers to understand that if a resistance had not been posed then it was going to be unbroken history of oppression, exploitation since colonial era. The unchanging time, and thus empty, is best reflected in the fourth letter:

On $2^{\text {nd }}$ May Asokmohan Chakraborty retired from the post of chief secretary. He declared that day, "All those entrusted with chief roles in administration must act neutral." Did he himself abide by this lofty principle? He has in fact acted as the office boy of CPM's office at Alimuddhin. Ardhendu acted as the door keeper, and DG Bhupinder demeaned himself even further. Home secretary Ardhendubabu is now the chief secretary. There is no question of his acting neutral. For last 2 years we have seen that Ardhendubabu is ever-eager for protection of harmads, 
and to save the leadership of CPM... But in spite of their efforts for 1 year they have been unsuccessful. Asokbabu retired and Ardhendu took his place. After him came Samar Ghosh. Even he will be gone sometime and some new man will take charge. But would these servants of the government listen to aspirations of the people, would they judge impartially? Standing on our motherland, since our forefathers we have been fighting for our honour, rights; in future our children will carry on the struggle. Whoever comes to silence our struggle for honour and aspirations - regardless of the degree of terror he unleashes - will not be successful. We shall get our rights through struggle. The people of Jangalmahal are the creators of tomorrow. (Sanhati 2013: 89-90)

From the above discussion therefore, another level of relations emerged, existing in the context of Lalgarh. This set of relations consist of both, everyday concrete and oblivious historical. While Harmad and paramilitary was an ever present concrete reality in Lalgarh; on the other hand, there was a historical time where nothing changed and all exploitation and oppression in the lawless land of JangalMahal stayed the same. It stretches back to colonial area and shall go on stretching in the future, unless interrupted.

\section{The Death and Rebirth of Sidhu Soren:} Becoming People, apolitical collective

The interruption came in the form of blockade and barricade. In the early days of the movement, right after the $2^{\text {nd }}$ November mine-blast and subsequent police atrocities, it has been noted, how genuine the anger of people was. The anger led them to come together in a spontaneous fashion and launch a movement, which would throw the police out of the area. In those days, the people very spontaneously instituted a social boycott of police, refusing them any services, including selling of goods. It is also reported that if any shopkeeper failed to oblige, he was made to do sit-ups, holding his ears. According to PCPA, at this juncture, Majhi Mawar Juan Gantao, an adivasi council of elders representing the adivasis was asked to give the movement a leadership and organize villagers' spontaneous anger. They agreed but eventually capitulated in front of the state government. Subsequently, adivasis rejected their leadership. In a meeting held at Dalilpur Chawk on $13^{\text {th }}$ November, PCPA was formed. In the fifth letter, it is further informed that it was not just the birth of PCPA but also the birth of Sidhu Soren.

In this meeting of 30000 people, Bhuta Baske -- a slander youth who was immensely popular among the villagers and at the fore front of the struggle by addressing media, voicing people's demand - was renamed Sidhu Soren, after Sidhu Murmu, the great martyr of the Santhal rebellion (1855-56). Ironically, in PCPA's narration, Bhuta Bakse's rebirth as Sidhu Soren coincides with his death. Sidhu Soren was the general secretary of PCPA and the "supreme commander" of Sidhu Kanu People's Militia. He was killed in a gun battle near Metala forest region on 26/07/2010 along with five other militia members. The police report described them as Maoists while PCPA's statement - issued on 01/08/2010 and included in the fifth letter, dated 05/08/2010 - describes them as members of PCPA. In the aftermath of his death, in the statement, it is declared that the Jagai Mundas of today would not be forgotten by the people for their betrayal. What is the betrayal? It is those people who had maintained secret ties with the police and harmads and 
passed on information about Sidhu Soren's whereabouts. Their action was comparable to the historic betrayal by Jagai Munda, responsible for the capture of Sidhu Murmu in the hands of British colonial forces. PCPA subtly implicates - and thus leaving little doubt about who these Jagai Mundas are - Majhi Mawar Juan Gantao and its members. However Majhi Mawar Juan Gantao's betrayal was not limited to alleged involvement in Sidhu Soren's death. Their betrayal was also betrayal of the people; as was Jagai Munda facilitating Sidhu Murmu's capture.

The facts presented above may be disputed and the narrative can be labelled as Maoist practice of eulogizing a fallen comrade. What however is interesting - to draw attention to it yet again - is not the meaning of the narrative but the structure. If the structure is scrutinized closely, what emerges as protagonist is not Sidhu Soren's death or his uncompromising spirit in defending adivasis. Sidhu Soren's heroic deeds can hardly be highlighted without the historical reference to Jagai Munda. And with the latter, the historical specificity of the name, Sidhu Murmu also comes to the fore. It is then the history which is the most important theme here.

This history - as it is told - is the history of Jangal Mahal for more than one century; but it is also history of the present. The letter recurrently juxtaposes Buddhadeb Bhattacharya, Manmohan Singh ${ }^{4}$ vis-à-vis earlier British rulers, alongside Sidhus versus Jagai Mundas. Thus the empty historical temporality hanging over the shoulder of the adivasis is not only reiterated but this time brought to the center. To allude to Althusser, it is also placed side by side the present condition of living in Lagarh. It is said,

...we have Manmohan Singh delivering speeches everyday on his hand out of 13000 crore rupees for tribal development. This has to be seen in the reverse manner. They are killing tribals, capturing tribal land just like the British. They are doing this to hand over the wealth to the US, Japan, Germany, and other imperialists. Hail the left front and Congress governments and the mercenary thug Cobras! Shame on you. (Sanhati 2013: 134-135)

Real history of Jangalmahal in the above quote is unmistakably history of the 'tribals' or adivasis as a community. Individuals, Sidhus and Jagai Mundas of the past or present are mere part of this history and actors who are fighting fantastic battle of antagonistic dialectics. Collective, to exploit Althusser's dramatised expression, has always remained at the wings.

For people, the collective to come, individuals must leave the center stage. I argue this is the real implication of the Sidhu Soren narrative. What it shows is how individual adivasis living amidst fear, secrecy and violence finally refusing to live in it and coming together. It also shows how such a movement from individualized body to collective, is premised on their subjectivity in search of connecting the everyday and history, otherwise dissociated. Bhuta Bakse by description was a slender and ordinary youth. It is then understood that he lived his life, along with his fellow villagers amidst the same violence, secrecy and at the fuzzy zone of law and order. It was a space where life was continually exposed to sovereign power to death. As all norms were suspended, a life was bereft of

${ }_{4}^{4}$ Then Chief Minister of West Bengal and the then Prime Minister of India respectively. 
minimum legal guarantee of life itself. Norm or law are set or bent according to persons (life) captured, killed or arrested. With respect to adivasis in Lalgarh anybody was sovereign and thus had the right to kill, by appropriating force of law; while law itself stays suspended in this state of exception (Agamben 2005). Such naked life has its parallel, according to Agamben (1998) in the Roman figure of Homo Sacer.

Homo Sacer a life which is excluded from both divine order and secular order. It can be killed but not sacrificed. In that sense, adivasis turned the figure of Homo Sacer on its head by renaming Bhuta Bakse as Sidhu Soren. An individual naked life was symbolically killed and then inscribed in history, inhabited by revered ancestors, a sacred order for the adivasis. Then political logic that this narrative reveals is subjectivity as I have defined it. In the act of renaming, individual villagers stepped outside the symbolic everyday of suspicion, secrecy and death; simultaneously they tried to connect the very disconnect between every day and history. However undoubtedly this political logic, teased out here is tainted by PCPA's highly romanticized idea of history and eulogizing Sidhu Soren. Without any independent source confirming the act of renaming did happen, it is methodologically consistent to consider it as an ideological trope. However despite being ideological, this narrative and the political logic derived from it still contains in it the real political process of subjectivity and becoming people, a political collective.

The birth of PCPA must now be in focus. Contrary to birth of Sidhu Soren, the formation of PCPA and adivasis' participation in it -- as has been seen in the beginning -- is a fact. So is the fact that adivasis rejected Majhi Mawar as the leaders of the movement. Unmistakably, there is a parallel between on the one hand, Bhuta Bakse's death and Sidhu Soren's birth in the symbolic world; and on the other rejection of Majhi Mawra and formation of PCPA in real material world. Majhi Mawar was a position of authority headed by the village elders, a power vested in them and legitimized by the adivasi tradition. Jagai Mundas or not, they were still the privileged section of adivasi population and their privilege being ensured by the historically developed shared ethos and norms. Thus ironically when adivasis rejected Majhi Mawar it was their historical tradition that itself they were suspending. Thus PCPA's unabashed romanticisation of the adivasi history, by celebrating Bhuta's rebirth as Sidhu becomes a more complex and nuanced process at the ground level. The fact that it is indeed a movement of consciousness is testified by antagonistic dialectics, internal (with Majhi Marwa) and external (the state) to adivasi community. If the adivasis did attempt to reclaim their history through the symbolic act of naming, they did not do so by uncritically accepting tradition as history.

Majhi Mawar was entrusted with the responsibility of leading the adivasis and in the process present the community as a political collective against the external enemy. However their failure only meant a new contradiction internal to community and as an extension very dissolution of the homogenous communitysentiment as a collective. The fact that they rejected Majhi Mawar in this process only implies their recognition of the contradictions in history itself. In the light of the fact that their history fraught with exploitation, betrayal and also struggle, they attempted to relate each component with the everyday. As opposed to exploitation at the hand of the state or betrayal by Majhi Mawar, lending legitimacy to PCPA's 
formation and subsequent participation -- just like naming Bhuta as Sidhu -- is an attempt to appropriate the history of struggle in the real, material world. It may not be a movement of consciousness, as complete and revolutionary as Marx envisaged for proletariat. However it is unmistakably a movement of consciousness. This movement of consciousness does not have a centered subject. As adivasis came together to form PCPA, as a form it structured adivasi population into the people, a political collective. But the people is never a centered subject. Becoming people is always-already a process as PCPA as a form may change with interventions of the people or a party like, CPI(Maoist) or new forms may develop alongside old. In return, the structuring of individuals as the people, by PCPA - or other forms shifts, alters and even oscillates.

Conceptualizing the people as a process in itself and as an outcome of a process of subjectivity without a subject has the advantage of going beyond the Party/agency debate. Both set of arguments, as mentioned in the beginning hold people's agency as the central object of investigation. While the supporters of Maoist line of politics argue for an internal process whereby Maoists emerge from the collective; for the opponents, Maoists are external to the people and thus threat to their agency. In this debate over externality/internality, the people remained assumed; so did the form of Maoist politics as CPI(Maoist). Let alone conceptualized, even it has not been hypothesized that the people's agency may be rooted in rendering Maoist politics a process too. Maoist intervention varies from one region to another region in Maoist controlled area. This variations cannot be accounted for by the assumption of external/internal duality and Maoist politics as a form as already given in CPI(Maoist). It can only be explained when one is open to the possibility that as the process of becoming people collide with the process of Maoist interventions, the form it takes may restructure differently both, people and the nature Maoist interventions.

\section{REFERENCES}

Agamben, Giorgio. 1998. Homo Sacer: Sovereign Power and Bare Life, translated by Daniel Heller-Roazen. Stanford, California: Stanford University Press.

-- - - 2005. The State of Exception, translated by Kevin Attell. London, UK: The University of Chicago Press.

Althuuser, Louis (2005), "The 'Piccolo Teatro': Bertolazzi and Brecht". Pp. 129-52 in For Marx. translated by Ben Brewster. New York, US: Verso.

- - - - 2006. "Ideology and Ideological State Apparatus (Notes Towards an Investigation)”. Pp. 85-126 in Lenin and Philosophy and other essays, Delhi, India: Aakar Books.

APDR and BMC, 2012. "Fact Finding Report on the Incidents of Violence at Nandigram during January, 2007” pp. 276-84. in Poschimbonge Rastriyo Santras: Kasipoor, Barahnagar theke Lalgarh via Singur-Nandigram, [State Terror in West Bengal: From Kasipoor, Barahnagar to Lalgarh, via SingurNandigram]. edited by Sukhdeb Chattopadhaya. Kolkata, India: Ubudash.

Badiou, Alain. 2005. "Althusser: Subjectivity without a Subject". pp. 58-67 in Metapolitics, translated by Jason Barker. New York, US: Verso. 
Bhattyacharya, Amit. 2010. "Is Lalgarh Showing the Way?". Economic and Political Weekly 44 (26\&27): 17-21.

D’Souza, Radha (2009). "Sandwich Theory and Operation Green Hunt", Sanhati. December $15 \quad$ (4097 words). Retrieved July 31, 2017 (http://sanhati.com/excerpted/2003/).

Gerth, H.H. and C. Wright Mills., ed. 1946. From Max Weber: Essays in Sociology, New York, US: Oxford University Press.

Giri, Saroj. 2009. "Lalgarh and the Radicalisation of Resistance: From 'Ordinary Civilians' to Political Subjects?". MRZine. July 09 (3465 words). Retrieved July 31, 2017 (https://mronline.org/2009/07/09/lalgarh-and-the-radicalisation-of-resistancefrom-ordinary-civilians-to-political-subjects/).

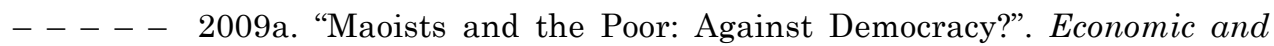
Political Weekly XLIV (49): 17-21.

Menon, Nivedita. 2009. "Radical Resistance and Political Violence Today". Economic and Political Weekly. 44(15): 16-20.

Nandini, Sundar, 2006. "Bastar, Maoism and Salwa Judum". Economic and Political Weekly 41(29): 3187-3192

Nigam, Aditya. 2009. "Democracy, State and Capital: The 'Unthought' of Twentieth Century Marxism, Economic and Political Weekly XLIV(51): 35-39.

- - - - 2010. "The Rumour of Maoism”. Seminar 607: 75-81.

Sanhati 2013. Letters from Lalgarh. Kolkata, India: Setu Prakashani.

Sarkar, Sumit and Tanika Sarkar. 2009, "Notes on a Dying People". Economic and Political Weekly XLIV(26-27): 10-14.

Shah, Alpa. 2009. "In search of certainty in revolutionary India". Dialectical Anthropology 33(3/4): 271-86.

Taussig, Michael. 1992. “Terror as Usual: Walter Benjamin's Theory of History as State of Siege”, Pp. 11-36 in The Nervous System, Newtork: Routledge.

White, Luise. 2000. Speaking with Vampires: Rumor and History in Colonial Africa. Berkeley, US: University of California Press. 